\title{
Factors affecting the survival of implants: a long-term retrospective study
}

\author{
Susanna Song, Jae-Kwan Lee, Heung-Sik Um, Beom-Seok Chang* \\ Department of Periodontology and Research Institute of Oral Sciences, Gangneung-Wonju National University College of \\ Dentistry, Gangneung, Republic of Korea
}

Purpose: The aim of the present study was to evaluate the long-term survival of implants retrospectively and determine the risk factors associated with implant failure. Materials and Methods: Of all implants that were placed at the Department of Periodontology of the Dental Hospital of Gangneung-Wonju National University from January 1998 to December 2012, 2265 implants that were followed up until June 2013 were included in this study. Data were collected from clinical and radiographic examinations from previous visits. The information gathered included gender, age, smoking status, implant diameter, implant length, surface of implant, location of implant within the dental arch, surgical techniques and existence of complications. Results: The survival rate before loading was $98.9 \%$. The cumulative survival rate after 5 years of loading was $97.2 \%$, and after 15 years of loading was $95.2 \%$. In a simple logistic regression analysis, gender $(P=0.016)$, smoking status $(P=0.001)$, location of implant $(P$ $=0.020)$ and existence of complications $(P=0.002)$ were statistically associated with implant failure and included in the multiple regression analysis. As a result of multiple logistic regression analysis, the variables statistically associated with implant failure $(P<$ $0.05)$ were smoking status $(P=0.049)$ and existence of complications $(P<0.001)$. Conclusion: The cumulative survival rate of dental implants after 15 years of loading was $95.2 \%$ and that the variables statistically associated with implant failure were smoking status and existence of complications. (J Dent Rehabil Appl Sci 2015;31(1):10-9)

Key words: dental implants; survival rate; retrospective study; risk factors

\section{Introduction}

Reconstruction of fully or partially edentulous areas with osseointegrated implants is one of the most reliable prosthetic treatments, with survival rates above $90 \%$ in long-term studies. ${ }^{1,2}$ Despite these high survival rates, there are still complications and failures in implant treatment. Previous studies have reported early failures in $0.7 \%$ to $7.4 \%$ of cases and late failures in $2.1 \%$ to $11.3 \%$ of cases. ${ }^{1}$ Therefore, the identification of risk factors associated with implant

*Correspondence to: Beom-Seok Chang

Professor, Department of Periodontology, Gangneung-Wonju National University

College of Dentistry, 7 Jukheon-gil, Gangneung, 210-702, Republic of Korea

Tel: +82-33-640-3188, Fax: +82-33-640-3113, E-mail: dentist@gwnu.ac.kr

Received: December 17, 2014/Last Revision: March 3, 2015/Accepted: March 2, 2015 failure is essential for treatment planning.

Risk factors for adverse outcomes range from implant design to coexisting systemic disease. ${ }^{3}$ In several studies, diabetes, steroid therapy, osteoporosis, chemotherapy, and head and neck irradiation have been considered to be contraindications for the placement of implants. ${ }^{4}$ Conversely, in other studies, individual medical problems did not correlate with an increase in implant failures. Rather, implant success was affected by bone quantity and quality and by surgical techniques. ${ }^{5} \mathrm{~A}$ variety of studies have reported that to-

Copyright $@ 2015$ The Korean Academy of Stomatognathic Function and Occlusion. (c) It is identical to Creative Commons Non-Commercial License. 
bacco use has a negative effect on implant survival. ${ }^{6,7}$ However, no obvious evidence has been presented concerning the influence of tobacco use on the survival rates of implants. ${ }^{2,7}$ The effect of a history of periodontal disease on implant failure is also controversial. Several authors reported that there may be an increased risk for implant failure in periodontally compromised patients, ${ }^{8,9}$ while other authors insisted that the presence of periodontal pathogens at periimplant sites does not necessarily indicate future implant failure. $^{10,11}$

Because the results obtained from numerous studies are contradictory, the questions raised by patients cannot be answered. In spite of the wide range of available studies, consistent conclusions cannot yet be drawn on the relationship between these factors and the long-term outcomes of implants. There is a clear need to obtain further scientific evidence in this area. Therefore, the aim of the present study was to evaluate the long-term survival of implants retrospectively and determine the risk factors associated with implant failure.

\section{Materials and Methods}

\section{Data collection}

A retrospective chart review was conducted for all implants that were placed at the Department of Periodontology of the Dental Hospital of GangneungWonju National University from January 1998 to December 2012 (IRB 2013-13). Of all implants that were included the chart review, only implants that were followed up until June 2013 were included in this study. Data were collected from clinical and radiographic examinations from previous visits. The information gathered included the following:

- Gender

- Age (classified into three categories: < 50 years, 50 - 59 years and $\geqq 60$ years)

- Smoking status (people smoking 1 cigarette or more per day at the time of implant placement were categorized as a smokers)

- Implant diameter (classified into three categories: $<3.75 \mathrm{~mm}, 3.75-4.5 \mathrm{~mm}, \geqq 5 \mathrm{~mm}$ )
- Implant length (classified into two categories: < $10 \mathrm{~mm}, \geqq 10 \mathrm{~mm}$, the classification criteria of $10 \mathrm{~mm}$ is based on the definition of a short implant $^{12}$ )

- Surface of implant (classified into three categories: blasted, sand-blasted and acid etched, and anodized surface)

- Location of implant within the dental arch (classified into four categories: maxillary anterior, maxillary posterior, mandibular anterior and mandibular posterior regions)

- Surgical techniques (specific procedures that were performed to place the implants: guided bone regeneration, sinus elevation with a crestal approach and sinus elevation with a lateral approach)

- Complications (biological and mechanical complications: peri-implant mucositis, peri-implantitis, implant periapical lesion and fracture of fixture, screw or prosthesis)

- Dates of implant placement, prosthesis placement, implant removal and the last follow-up visit An implant failure was defined as the removal of the implant for any reason. ${ }^{13}$ Implants were regarded as surviving when they were present in the oral cavity at follow-up visits. Total survival time was defined as the period from the date of implant placement to the date of implant removal or the last follow-up visit. ${ }^{13}$ Implant failure was classified as early failure if it occurred before functional loading, or late failure if it occurred after functional loading. ${ }^{14}$

\section{Statistical analyses}

After the data collection, statistical analyses were performed. The cumulative survival rates of implants were calculated by the life table method at annual intervals and a Kaplan-Meier survival curve was obtained. To determine the potential risk factors associated with implant failure, a simple logistic regression analysis was performed. Implant failure was the dependent variable and all independent variables were entered separately as categorical variables. Following the simple regression analysis, independent variables with $P<0.1$ were selected and included in a multiple regression analysis to eliminate possible 
confounding variables. A multiple logistic regression analysis was performed for implant failure as the dependent variable and independent variables with $P<0.05$ were considered statistically associated with implant failure. In all types of analyses, each implant was regarded as the analysis unit. Thus multiple implants from the same patient had the same patientrelated covariates. All analyses were conducted using statistical software (SPSS $^{\text {TM }}$ 20, IBM Inc., Chicago, IL, USA).

\section{Results}

During the period from January 1998 to December 2012, 5019 implants were placed in 1921 patients. Of these patients, 1146 were excluded from this study because of a lack of follow-up visits. Thus the study group was composed of 2265 implants from 775 patients.

\section{Demographic characteristics}

The study group consisted of 296 females and 479 males. The mean age at the last visit was 55.5 years (range: 19 to 81 years). Of 2265 implants, 854 implants $(37.7 \%)$ were placed in females, and 1411 implants $(62.3 \%)$ were placed in males. Six hundred thirty-four implants $(28.0 \%)$ were placed in smokers, and 1631 implants $(72.0 \%)$ were placed in nonsmokers (Table 1).

\section{Implant characteristics}

The majority of the implants were of a diameter $\geqq 3.75 \mathrm{~mm}(95.3 \%)$, and $4.7 \%$ were of a diameter $<3.75 \mathrm{~mm}$. Most of the implants were $\geqq 10 \mathrm{~mm}$ $(95.8 \%)$ in length. The implants had a variety of surfaces including blasted (49.2\%), anodized (30.7\%), and SLA surfaces (20.1\%) (Table 2).

Table 1. Distribution of implants according to demographic characteristics

\begin{tabular}{|c|c|c|c|}
\hline & & Placed implants $(\mathrm{n}=2265)$ & Failed implants $(\mathrm{n}=55)$ \\
\hline & & $\mathrm{N}(\%)$ & $\mathrm{N}(\%)$ \\
\hline \multirow[t]{2}{*}{ Gender } & Female & $854(37.7)$ & $12(1.4)$ \\
\hline & Male & $1411(62.3)$ & $43(3.0)$ \\
\hline \multirow[t]{3}{*}{ Age (yr) } & $<50$ & $413(18.2)$ & $13(3.1)$ \\
\hline & $50-59$ & $1083(47.8)$ & $25(2.3)$ \\
\hline & $\geq 60$ & $769(34.0)$ & $17(2.2)$ \\
\hline \multirow[t]{2}{*}{ Smoking } & No & $1631(72.0)$ & $28(1.7)$ \\
\hline & Yes & $634(28.0)$ & $27(4.3)$ \\
\hline
\end{tabular}

Table 2. Distribution of implants according to implant characteristics

\begin{tabular}{llcr}
\hline & & Placed implants $(\mathrm{n}=2265)$ & Failed implants $(\mathrm{n}=55)$ \\
& & $\mathrm{N}(\%)$ & $\mathrm{N}(\%)$ \\
\hline Diameter $(\mathrm{mm})$ & $<3.75$ & $106(4.7)$ & $39(2.5)$ \\
& $3.75-4.5$ & $1547(68.3)$ & $12(2.0)$ \\
Length $(\mathrm{mm})$ & $\geq 5$ & $612(27.0)$ & $51(2.4)$ \\
& $\geq 10$ & $2170(95.8)$ & $4(4.2)$ \\
Surface & $<10$ & $95(4.2)$ & $22(2.0)$ \\
& Blasted & $1115(49.2)$ & $19(2.7)$ \\
& Anodized & $696(30.7)$ & $14(3.1)$ \\
\hline
\end{tabular}




\section{Surgical characteristics and the existence of complications}

One thousand one hundred and twenty-five implants were inserted in the maxilla (195 in the anterior and 930 in the posterior) and 1140 in the mandible (75 in the anterior and 1065 in the posterior). The guided bone regeneration (GBR) technique was used in 559 implants, and 368 implants were placed after maxillary sinus elevation (198 with the crestal approach and 170 with the lateral approach). The others (1338 implants) were placed without any specific procedure. Postoperative complications including peri-implant mucositis, peri-implantitis, implant periapical lesions and fractures of the fixture, screw or prosthesis occurred in 354 implants (15.6\%) (Table $3)$.

\section{Implant survival}

Of the 2265 inserted implants, 55 (2.4\%) failed. Twenty-five implants (1.1\%) failed before loading (early) and $30(1.3 \%)$ failed after loading (late). According to the Kaplan-Meier lifetime analysis (Table 4, Fig. 1), the cumulative survival rate after 5 years of loading was $97.2 \%$, and after 15 years of loading was $95.2 \%$.
Table 4. Cumulative survival rate of inserted implants

\begin{tabular}{cccc}
\hline Time (yr) & $\begin{array}{c}\text { No. of } \\
\text { implants at } \\
\text { beginning of } \\
\text { interval }\end{array}$ & $\begin{array}{c}\text { No. of } \\
\text { failed implants } \\
\text { during interval }\end{array}$ & $\begin{array}{c}\text { Cumulative } \\
\text { survival rate } \\
(\%)\end{array}$ \\
\hline Place / Load & 2265 & 25 & 98.9 \\
Load / 1 & 2082 & 4 & 98.7 \\
1 to 2 & 1699 & 8 & 98.2 \\
2 to 3 & 1398 & 8 & 97.6 \\
3 to 4 & 1093 & 2 & 97.4 \\
4 to 5 & 834 & 2 & 97.2 \\
5 to 6 & 651 & 1 & 97.0 \\
6 to 7 & 478 & 0 & 97.0 \\
7 to 8 & 326 & 2 & 96.4 \\
8 to 9 & 253 & 3 & 95.2 \\
9 to 10 & 141 & 0 & 95.2 \\
10 to 11 & 43 & 0 & 95.2 \\
11 to 12 & 13 & 0 & 95.2 \\
12 to 13 & 2 & 0 & 95.2 \\
13 to 14 & 2 & 0 & 95.2 \\
14 to 15 & 2 & 05.2 \\
\hline
\end{tabular}

Place / Load: placement of implant to time of loading. Load / 1: time of loading to 1 year.

Table 3. Distribution of the implants according to surgical characteristics and the existence of complications

\begin{tabular}{llcr}
\hline & & Placed implants $(\mathrm{n}=2265)$ & Failed implants $(\mathrm{n}=55)$ \\
\hline Location & Maxillary anterior & $\mathrm{N}(\%)$ & $\mathrm{N}(\%)$ \\
& Maxillary posterior & $195(8.6)$ & $3(1.5)$ \\
& Mandibular anterior & $930(41.1)$ & $33(3.5)$ \\
& Mandibular posterior & $75(3.3)$ & $2(2.7)$ \\
Surgical technique & GBR & $1065(47.0)$ & $17(1.6)$ \\
& Sinus elevation (Crestal) & $559(24.7)$ & $14(2.5)$ \\
& Sinus elevation (Lateral) & $198(8.7)$ & $7(3.5)$ \\
& Conventional & $170(7.5)$ & $4(2.4)$ \\
Complications & $1338(59.1)$ & $30(2.2)$ \\
& Absence & $1911(84.4)$ & $35(1.8)$ \\
& Presence & $354(15.6)$ & $20(5.6)$ \\
\hline
\end{tabular}

GBR, guided bone regeneration. 


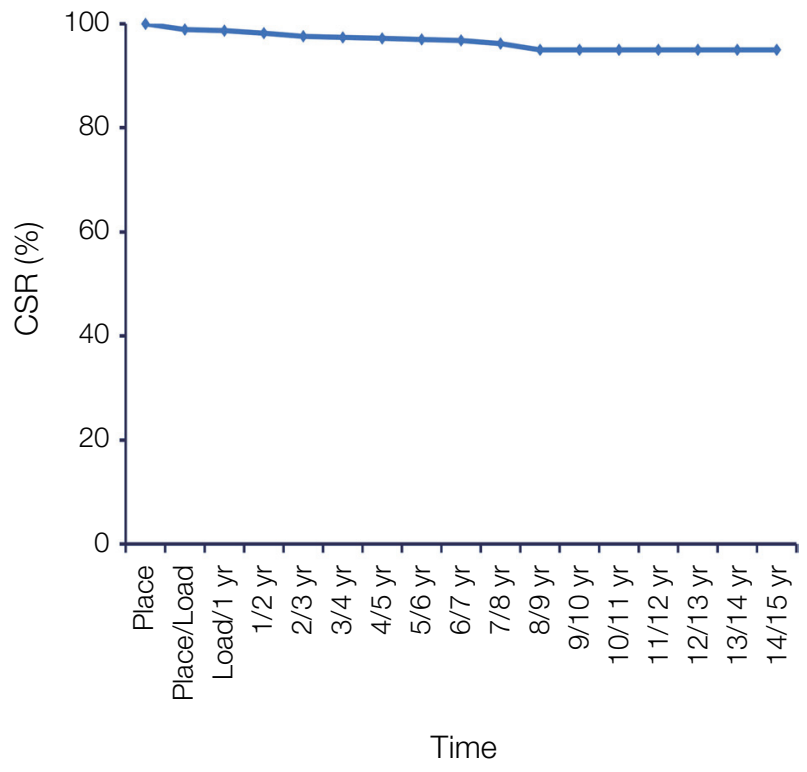

Fig. 1. Kaplan-Meier survival curve. CSR, cumulative survival rate.

\section{Risk factors associated with implant failure}

All independent variables including gender, age, smoking status, implant diameter, implant length, surface of implant, location of implant, surgical technique and existence of complications were entered into a simple logistic regression analysis (Table 5 - 7). Among these variables, gender $(P=0.016)$, smoking status $(P=0.001)$, location of implant $(P=0.020)$ and existence of complications $(P=0.002)$ were statistically associated with implant failure and included in the multiple regression analysis.

As a result of multiple logistic regression analysis (Table 8$)$, the variables statistically associated with implant failure $(P<0.05)$ were smoking status $(P=$ $0.049)$ and existence of complications $(P<0.001)$.

Table 5. Simple logistic regression analysis for risk factors associated with implant failure (Demographic variables)

\begin{tabular}{llccc}
\hline & & Odds ratio & $95 \%$ Confidence Interval & $P$ value \\
\hline Gender & & & & $0.016^{*}$ \\
& Female (baseline) & & & \\
& Male & 2.206 & & 0.016 \\
Age (yr) & & & 0.526 \\
& $<50$ (baseline) & & & \\
& $50-59$ & 0.757 & 0.385 to 1.487 & 0.419 \\
& $\geq 60$ & 0.654 & 0.311 to 1.373 & 0.262 \\
Smoking & & & $0.001^{*}$ \\
& No (baseline) & & & 0.001 \\
& Yes & 2.547 & 1.489 to 4.356 & \\
\hline
\end{tabular}

*Significant association $(P<0.1)$.

Table 6. Simple logistic regression analysis for risk factors associated with implant failure (Implant variables)

\begin{tabular}{|c|c|c|c|}
\hline & Odds ratio & $95 \%$ Confidence Interval & $P$ value \\
\hline Diameter (mm) & & & 0.495 \\
\hline \multicolumn{4}{|l|}{$<3.75$ (baseline) } \\
\hline $3.75-4.5$ & 0.659 & 0.231 to 1.881 & 0.436 \\
\hline$\geq 5$ & 0.510 & 0.161 to 1.612 & 0.252 \\
\hline Length (mm) & & & 0.256 \\
\hline \multicolumn{4}{|l|}{$\geq 10$ (baseline) } \\
\hline$<10$ & 1.826 & 0.646 to 5.162 & 0.256 \\
\hline Surface & & & 0.361 \\
\hline Blasted (baseline) & & & \\
\hline Anodized & 1.394 & 0.749 to 2.595 & 0.294 \\
\hline SLA & 1.581 & 0.802 to 3.118 & 0.186 \\
\hline
\end{tabular}


Table 7. Simple logistic regression analysis for risk factors associated with implant failure (surgical variables and complications)

\begin{tabular}{lccc}
\hline & Odds ratio & 95\% Confidence interval & $P$ value \\
\hline Location & & & $0.020^{*}$ \\
Maxillary anterior (baseline) & & 0.738 to 7.988 & 0.144 \\
Maxillary posterior & 2.429 & 0.287 to 10.708 & 0.543 \\
Mandibular anterior & 1.753 & 0.282 to 3.382 & 0.970 \\
Mandibular posterior & 0.976 & & 0.672 \\
Surgical technique & & 0.534 to 3.309 & 0.541 \\
GBR (baseline) & & 0.286 to 2.669 & 0.813 \\
Sinus elevation (Crestal) & 1.329 & 0.427 to 1.511 & 0.497 \\
Sinus elevation (Lateral) & 0.874 & & $0.002 *$ \\
Conventional & 0.803 & & 0.002 \\
Complications & & 1.387 to 4.457 & \\
Absence (baseline) & & & \\
Presence & 2.486 & & \\
\hline
\end{tabular}

GBR, guided bone regeneration.

Table 8. Multiple logistic regression analysis for risk factors associated with implant failure

\begin{tabular}{|c|c|c|c|}
\hline Variables & Odds ratio & $95 \%$ Confidence interval & $P$ value \\
\hline Gender & & & 0.272 \\
\hline \multicolumn{4}{|l|}{ Female (baseline) } \\
\hline Male & 1.501 & 0.727 to 3.098 & 0.272 \\
\hline Smoking & & & $0.049 *$ \\
\hline \multicolumn{4}{|l|}{ No (baseline) } \\
\hline Yes & 1.839 & 1.002 to 3.377 & 0.049 \\
\hline Location & & & 0.085 \\
\hline \multicolumn{4}{|c|}{ Maxillary anterior (baseline) } \\
\hline Maxillary posterior & 2.395 & 0.722 to 7.943 & 0.153 \\
\hline Mandibular anterior & 1.895 & 0.306 to 11.726 & 0.492 \\
\hline Mandibular posterior & 1.166 & 0.336 to 4.055 & 0.809 \\
\hline Complications & & & $<0.001 *$ \\
\hline \multicolumn{4}{|l|}{ Absence (baseline) } \\
\hline Presence & 2.977 & 1.685 to 5.258 & $<0.001$ \\
\hline
\end{tabular}

*Significant association $(P<0.05)$.

The implants placed in smokers were 1.839 times more likely to fail than the implants placed in nonsmokers. The implants with complications were also at a greater risk of failure compared to the implants without complications, with an odds ratio of $2.977: 1$.

\section{Discussion}

The purpose of this retrospective study was to analyze the long-term outcomes of 2265 implants and determine the risk factors associated with implant failure. A retrospective chart review of implants placed at the department of periodontology of the dental hospital of Gangneung-Wonju national university from January 1998 to December 2012 was performed.

In the present study, the cumulative survival rate up to 15 years was $95.2 \%$. Previously, Simonis et al. ${ }^{15}$ reported a long-term cumulative survival rate of $82.94 \%$ up to 16 years. Additionally, Roos-Jansåker 
et al. ${ }^{2}$ assessed the long-term outcome of implant therapy and reported that the overall survival rate up to 14 years was $95.7 \%$. Thus, the outcome of the present study is consistent with previous studies.

In this study, only 55 implants were removed. Some of these were concentrated in a small number of individuals. Fifty-five implant removals occurred in 47 patients and 15 of 55 removed implants were in 7 patients. Among them, five were smokers and two were non-smokers. Peri-implantitis occurred in 2 patients and implant periapical lesion occurred in 1 patient.

To identify the risk factors associated with implant failure, statistical analyses were performed. Using multiple logistic regression analysis, a significant relationship was found between implant failure and independent variables including smoking status and existence of complications. Smoking status has previously been regarded as a risk factor for implant failure. Bain and $\mathrm{Moy}^{16}$ reported a failure rate of $11.3 \%$ in smokers and $4.76 \%$ in non-smokers. In more recent study, Huynh-Ba et al. ${ }^{17}$ studied 273 implants placed in the posterior maxilla and reported that smoking markedly increased the risk for implant failure. In terms of existence of complications, Simonis et al. ${ }^{15}$ referred to peri-implantitis as a complication with a very high risk of implant loss; of 21 cases, only 5 implants were functional after 16 years despite comprehensive treatments including implant debridement and administration of systemic antibiotics.

Some variables that were not significantly related to implant failure in multiple regression analysis but reached statistical significance in simple regression analysis included gender and location of implant. Males (odds ratio $=1.501$ ) and maxillary posterior implants (odds ratio $=2.395$ ) were associated with implant failure. These variables were previously identified as risk factors for implant failure. Zupnik et al. ${ }^{18}$ reported that gender was the parameter with the strongest correlation with implant failure in a metaanalysis that demonstrated that males had a higher prevalence of destructive periodontal disease. ${ }^{19} \mathrm{Be}$ cause periodontal disease is widely recognized as a risk factor for peri-implantitis and implant failure, ${ }^{20,21}$ the higher prevalence of periodontal disease in males may explain the outcome of the study. Anitua et al. ${ }^{22}$ reported significantly lower survival for implants placed in the maxilla compared to the mandible. This difference might be the outcome of the less favorable osseous situation in patients requiring maxillary reconstruction. In addition, Moy et al. ${ }^{3}$ studied 4680 implants in 1140 patients and reported that implants placed in the maxilla failed at almost twice rate of those placed in the mandible.

The present study had some limitations. First, an inherent limitation of retrospective studies is a risk for bias because only the implants that were followed up were included in the study group. The dropout rate (1146 of 1921 patients, 59.7\%) could be considered high and must be considered when interpreting the results. Previous studies have suggested this as a reason for incomplete results. ${ }^{17,23}$ Second, because the number of failed implants was very low (55 of 2265 implants, 2.4\%), definitive conclusions could not be drawn. Alsaadi et al. ${ }^{24}$ reported that due to the low number of implant failures, only potentially influential factors could be identified. Finally, numerous variables that are known to be significantly associated with implant failure were not included in our analyses. For example, diabetes has been significantly correlated with implant failure. ${ }^{18}$ Rodrigo et al..$^{25}$ reported that resonance frequency analysis (RFA) values at restoration placement could significantly predict the outcomes of implants. Quirynen et al. ${ }^{26}$ reported that a large proportion of failing implants may be explained by the lack of proper supportive periodontal therapy (SPT), and Ong et al. ${ }^{27}$ proposed that the irregularity of SPT might influence the outcomes and differences between studies. Therefore, well-designed, controlled prospective studies that consider the above limitations are required.

\section{Conclusion}

We conclude that the cumulative survival rate of dental implants after 15 years of loading was $95.2 \%$ and that the variables statistically associated with implant failure were smoking status and existence of complications. 


\section{References}

1. Berglundh T, Persson L, Klinge B. A systematic review of the incidence of biological and technical complications in implant dentistry reported in prospective longitudinal studies of at least 5 years. J Clin Periodontol 2002;29:197-212.

2. Roos-Jansåker AM, Lindahl C, Renvert H, Renvert S. Nine- to fourteen-year follow-up of implant treatment. Part I: Implant loss and associations to various factors. J Clin Periodontol 2006;33:283-9.

3. Moy PK, Medina D, Shetty V, Aghaloo TL. Dental implant failure rates and associated risk factors. Int J Oral Maxillofac Implants 2005;20:569-77.

4. Fugazotto PA. Success and failure rates of osseointegrated implants in function in regenerated bone for 6 to 51 months: a preliminary report. Int J Oral Maxillofac Implants 1997;12:17-24.

5. Smith RA, Berger R, Dodson TB. Risk factors associated with dental implants in healthy and medically compromised patients. Int J Oral Maxillofac Implants 1992;7:367-72.

6. Bain CA. Implant installation in the smoking patient. Periodontol 2000 2003;33:185-93.

7. Strietzel FP, Reichart PA, Kale A, Kulkarni M, Wegner B, Küchler I. Smoking interferes with the prognosis of dental implant treatment: a systematic review and meta-analysis. J Clin Periodontol 2007;34:523-44.

8. Karoussis IK, Salvi GE, Heitz-Mayfield LJ, Brägger $\mathrm{U}$, Hämmerle CH, Lang NP. Long-term implant prognosis in patients with and without a history of chronic periodontitis: a 10-year prospective cohort study of the ITI dental implant system. Clin Oral Implants Res 2003;14:329-39.

9. Evian CI, Emling R, Rosenberg ES, Waasdorp JA, Halpern W, Shah S, Garcia M. Retrospective analysis of implant survival and the influence of periodontal disease and immediate placement on longterm results. Int J Oral Maxillofac Implants 2004; 19:393-8.

10. Sbordone L, Barone A, Ciaglia RN, Ramaglia L, Iacono VJ. Longitudinal study of dental implants in a periodontally compromised population. J Periodontol 1999;70:1322-9.
11. Nevins M. Will implants survive well in patients with a history of inflammatory periodontal disease? J Periodontol 2001;72:113-7.

12. Morand M, Irinakis T. The challenge of implant therapy in the posterior maxilla: providing a rationale for the use of short implants. J Oral Implantol 2007;33:257-66.

13. Chuang SK, Wei LJ, Douglass CW, Dodson TB. Risk factors for dental implant failure: a strategy for the analysis of clustered failure-time observations. J Dent Res 2002;81:572-7.

14. Lang NP, Karring T, Meredith N. Group E summary. J Clin Periodontol 2002;29:232-4.

15. Simonis P, Dufour T, Tenenbaum H. Long-term implant survival and success: a 10-16-year followup of non-submerged dental implants. Clin Oral Implants Res 2010;21:772-7.

16. Bain CA, Moy PK. The association between the failure of dental implants and cigarette smoking. Int J Oral Maxillofac Implants 1993;8:609-15.

17. Huynh-Ba G, Friedberg JR, Vogiatzi D, Ioannidou E. Implant failure predictors in the posterior maxilla: a retrospective study of 273 consecutive implants. J Periodontol 2008;79:2256-61.

18. Zupnik J, Kim SW, Ravens D, Karimbux N, Guze K. Factors associated with dental implant survival: a 4-year retrospective analysis. J Periodontol 2011;82:1390-5.

19. Shiau HJ, Reynolds MA. Sex differences in destructive periodontal disease: a systematic review. J Periodontol 2010;81:1379-89.

20. Baelum V, Ellegaard B. Implant survival in periodontally compromised patients. J Periodontol 2004;75:1404-12.

21. Ferreira SD, Silva GL, Cortelli JR, Costa JE, Costa FO. Prevalence and risk variables for peri-implant disease in Brazilian subjects. J Clin Periodontol 2006;33:929-35.

22. Anitua E, Orive G, Aguirre JJ, Ardanza B, Andía I. 5-year clinical experience with BTI dental implants: risk factors for implant failure. J Clin Periodontol 2008;35:724-32.

23. Scurria MS, Morgan ZV 4th, Guckes AD, Li S, Koch G. Prognostic variables associated with implant failure: a retrospective effectiveness study. Int 
J Oral Maxillofac Implants 1998;13:400-6.

24. Alsaadi G, Quirynen M, Michiles K, Teughels W, Komárek A, van Steenberghe D. Impact of local and systemic factors on the incidence of failures up to abutment connection with modified surface oral implants. J Clin Periodontol 2008;35:51-7.

25. Rodrigo D, Aracil L, Martin C, Sanz M. Diagnosis of implant stability and its impact on implant survival: a prospective case series study. Clin Oral Implants Res 2010;21:255-61.
26. Quirynen M, Abarca M, Van Assche N, Nevins M, van Steenberghe D. Impact of supportive periodontal therapy and implant surface roughness on implant outcome in patients with a history of periodontitis. J Clin Periodontol 2007;34:805-15.

27. Ong CT, Ivanovski S, Needleman IG, Retzepi M, Moles DR, Tonetti MS, Donos N. Systematic review of implant outcomes in treated periodontitis subjects. J Clin Periodontol 2008;35:438-62. 


\section{임플란트의 생존에 영향을 미치는 요인에 대한 장기간의 후향적 연구}

\section{송수산나, 이재관, 엄흥식, 장범석*}

강릉원주대학교 치과대학 치주과학교실

목적: 이 연구는 임플란트의 장기간 생존율을 후향적으로 평가하고, 이에 영향을 미치는 요인을 분석하는 것이었다.

연구 재료 및 방법: 1998년 1월부터 2012년 12월까지 강릉원주대학교 치과병원 치주과에서 식립된 임플란트 중 2013 년 6월까지 주기적으로 검사가 이루어지고 있는 2265개의 임플란트를 대상으로 하였다. 환자의 진료기록부와 방사선 사진을 통해 성별, 연령, 흡연 여부, 임플란트 직경, 임플란트 길이, 임플란트 표면, 임플란트 식립 부위, 동반된 술식, 합 병증 유무에 대한 자료를 조사하였다.

결과: 임플란트 식립 후 보철 전 생존율은 98.9\%, 보철 후 5년간 누적생존율은 $97.2 \%, 15$ 년간 누적생존율은 $95.2 \%$ 이 었다. 단순로지스틱회귀분석 시 성별, 흡연 여부, 임플란트 식립 부위 및 합병증 유무가 임플란트 실패와 유의하게 관 련되었다. 이 변수들로 다중로지스틱회귀분석을 시행한 결과, 흡연 여부와 합병증 유무만이 임플란트 실패와 유의하게 관련된 것으로 나타났다.

결론: 2265 개의 임플란트를 대상으로 15 년간의 누적생존율을 조사한 결과 $95.2 \%$ 이었다. 흡연가이거나, 임플란트 합 병증이 존재할 경우 임플란트의 실패율이 유의하게 증가되었다.

(구강회복응용과학지 2015;31 (1): 10-9)

주요어: 치과용 임플란트; 생존율; 후향적 연구; 위험 요인

*교신저자: 장범석

(210-702) 강원도 강릉시 죽헌길 7 강릉원주대학교 치과대학 치주과학교실

Tel: 033-640-3188 | Fax: 033-640-3113 | E-mail: dentist@gwnu.ac.kr

접수일: 2014년 12월 17일 | 수정일: 2015년 3월 3일 | 채택일: 2015년 3월 2일 